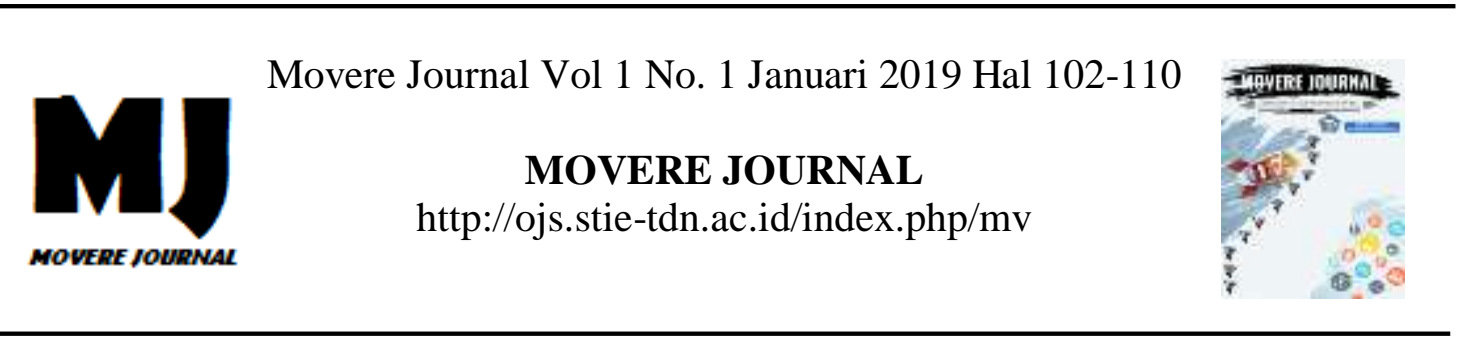

\title{
EFEKTIVITAS PENGELOLAAN MANAJEMEN KEUANGAN SEKOLAH PADA MTS SALILAMA KECAMATAN MANANGGU KABUPATEN BOALEMO
}

\author{
Tamsir \\ STIE Ichsan Pohuwato Gorontalo
}

\begin{abstract}
Abstrak: Tujuan penelitian ini adalah untuk mengetahui dan menganalisis efektivitas pengelolaan keuangan sekolah pada MTs Salilama Kecamatan Mananggu Kabupaten Boalemo. Berdasarkan pada hasil olahan data dengan menggunakan metode persentase Dari hasil olahan data hasil perhitungan menunjukkan bahwa pengelolaan keuangan MTs Salilama Kecamatan Mananggu sudah efektif sebab dalam hal ini Lembaga pendidikan MTs Salilama dalam menyusun perencanaan keuangan sekolah dilakukan ketika akan memasuki awal tahun pembelajaran baru dimulai dengan melibatkan tenaga pendidik terkait dan komite sekolah serta dalam penyusunan perencanaan keuangan sekolah atau Rancangan Anggaran Pendapatan dan Belanja Sekolah (RAPBS) pihak pengelola MTs Salilama nampaknya berusaha untuk menyusun Rancangan Anggaran Pendapatan Belanja Sekolah (RAPBS) berdasarkan pada efektif dan efesien yang sesuai dengan tanggapan responden sebesar $100 \%$. Namun dalam pelaksanaan manajemen keuangan sekolah yang berlaku pihak manajemen keuangan sekolah mengalami sedikit kendala, namun kendala yang dihadapi pihak manajemen sekolah mengadakan pertemuan guna mendapatkan solusi yang terbaik, hal ini terlihat pada hasil tanggapan responden sebesar $71 \%$.
\end{abstract}

Kata kunci: efektivitas, pengelolaan keuangan sekolah

\section{PENDAHULUAN}

Sekolah adalah sebuah aktifitas besar yang di dalamnya ada empat komponen yang saling berkaitan. Empat komponen yang di maksud adalah Staf Tata laksana Administrasi, Staf Teknis pendidikan didalamnya ada Kepala Sekolah dan Guru, Komite sekolah sebagai badan independent yang membantu terlaksananya operasional pendidikan, dan siswa sebagai peserta didik yang bisa di tempatkan sebagai konsumen dengan tingkat pelayanan yang harus memadai. Hubungan keempatnya harus sinergis, karena keberlangsungan operasioal sekolah terbentuknya dari hubungan "simbiosis mutualis" keempat komponen tersebut karena kebutuhan akan pendidikan demikian tinggi, tentulah harus dihadapi dengan kesiapan yang optimal semata-mata demi kebutuhan anak didik.

Salah satu unsur yang penting dimiliki oleh suatu sekolah agar menjadi sekolah yang dapat mencetak anak didik yang baik adalah dari segi keuangan. Manajemen keuangan sekolah sangat penting hubungannya dalam pelaksanaan kegiatan sekolah, demikian halnya pada MTs Salilama Kecamatan Mananggu Kabupaten Boalemo.

Ada beragam sumber dana yang dimiliki oleh suatu sekolah, baik dari pemerintah maupun pihak lain. Ketika 
dana masyarakat atau dana pihak ketiga lainnya mengalir masuk, harus dipersiapkan sistem pengelolaan keuangan yang professional dan jujur. Pengelolaan keuangan secara umum sebenarnya telah dilakukan dengan baik oleh semua sekolah. Hanya kadang substansi implementasinya yang beragam antara sekolah yang satu dengan yang lainnya.

Adanya keragaman ini bergantung kepada besar kecilnya tiap sekolah, letak sekolah dan julukan sekolah. Pada sekolah-sekolah biasa yang daya dukung masyarakatnya masih tergolong rendah, pengelolaan keuangannya pun masih sederhana. Sedangkan, pada sekolah-sekolah biasa yang daya dukung masyarakatnya besar, bahkan mungkin sangat besar, tentu saja pengelolaan keuangannya cenderung menjadi lebih rumit. Kecenderungan ini dilakukan karena sekolah harus mampu menampung berbagai kegiatan yang semakin banyak dituntut oleh masyarakatnya.

Adapun rumusan masalahnya adalah:“"Apakah pengelolaan keuangan sekolah pada MTs Salilama Kecamatan Mananggu Kabupaten Boalemo sudah berjalan dengan efektif'.

\section{LANDASAN TEORI Manajemen Keuangan Sekolah}

Pendidikan adalah salah satu bidang yang didesentralisasikan pengelolaannya kepada daerah, sehingga kepala sekolah selaku pengendali manajemen pengelolaan keuangan pendidikan/sekolah harus bertanggung jawab kepada Bupati/Walikota melalui kepala satuan kerja perangkat daerah yang membidanginya. Keuangan dan pembiayaan merupakan salah satu sumber daya yang secara langsung menunjang efektifitas dan efisiensi pengelolaan pendidikan.
Hal tersebut lebih terasa lagi dalam implementasi Manajemen Berbasis Sekolah (MBS), yang menuntut kemampuan sekolah untuk merencanakan, melaksanakan dan mengevaluasi serta mempertanggung jawabkan pengelolaan dana secara transparan kepada masyarakat dan pemerintah (Suryana 2008:19). Dalam penyelenggaraan pendidikan, keuangan dan pembiayaan merupakan potensi yang sangat menentukan dan merupakan bagian yang tak terpisahkan dalam kajian manajemen pedidikan.

Komponen keuangan dan pembiayaan pada suatu sekolah merupakan komponen produksi yang menentukan terlaksananya kegiatan belajar mengajar di sekolah bersama dengan komponen-komponen yang lain. Dengan kata lain setiap kegiatan yang dilakukan sekolah memerlukan biaya, baik itu disadari maupun yang tidak disadari. Komponen keuangan dan pembiayaan ini perlu dikelola sebaik-baiknya, agar dana yang ada dapat dimanfaatkan secara optimal untuk menunjang tercapainya tujuan pendidikan.

Hal ini penting, terutama dalam rangka MBS, yang memberikan kewenangan kepada sekolah untuk mencari dan memanfaatkan berbagai sumber dana sesuai dengan kebutuhan masing-masing sekolah karena pada umumnya dunia pendidikan selalu dihadapkan pada masalah keterbatasan dana, apa lagi dalam kondisi krisis pada sekarang ini (Mulyasa 2007:37).

Menurut Suryana (2008:21) bahwa sumber keuangan dan pembiayaan pada suatu sekolah secara garis besar dapat dikelompokkan atas tiga sumber, yaitu (1) pemerintah, baik pemerintah pusat, daerah maupun kedua duanya, yang bersifat umum atau khusus dan diperuntukkan bagi kepentingan pendidikan; (2) orang tua atau peserta didik; (3) masyarakat, baik mengikat 
maupun tidak mengikat. Berkaitan dengan penerimaan keuangan dari orang tua dan masyarakat ditegaskan dalam Undang-Undang No. 20/2003 tentang Sistem Pendidikan Nasional bahwa karena keterbatasan kemampuan pemerintah dalam pemenuhan kebutuhan dana pendidikan, tanggung jawab atas pemenuhan dana pendidikan merupakan tanggung jawab bersama antara pemerintah, masyarakat dan orang tua.

Dimensi pengeluaran meliputi biaya rutin dan biaya pembangunan. Biaya rutin adalah biaya yang harus dikeluarkan dari tahun ke tahun, seperti gaji pegawai (guru dan non guru), serta biaya operasional, biaya pemeliharaan gedung, fasilitas dan alat-alat pengajaran (barang-barang habis pakai). Sementara biaya pembangunan misalnya biaya pembelian atau pengembangan tanah, pembangunan gedung, perbaikan atau rehab gedung, penambahan furnitur, serta biaya atau pengeluaran lain untuk barang-barang yang tidak habis pakai.

Dalam implementasi MBS, manajemen komponen keuangan harus dilaksanakan dengan baik dan teliti mulai dari tahap penyusunan anggaran, penggunaan, sampai pengawasan dan pertanggungjawaban sesuai dengan ketentuan yang berlaku agar semua dana sekolah benar-benar dimanfaatkan secara efektif, efisien, tidak ada kebocoran, serta bebas dari penyakit korupsi, kolusi dan nepotisme (KKN) Suryana (2008:26).

\section{Tujuan Manajemen Keuangan Sekolah}

Melalui kegiatan manajemen keuangan maka kebutuhan pendanaan kegiatan sekolah dapat direncanakan, diupayakan pengadaannya, dibukukan secara transparan, dan digunakan untuk membiayai pelaksanaan program sekolah secara efektif dan efisien. Untuk itu tujuan manajemen keuangan sekolah menurut Suryana (2008:37) adalah :

1) Meningkatkan efektivitas dan efisiensi penggunaan keuangan sekolah.

2) Meningkatkan akuntabilitas dan transparansi keuangan sekolah.

3) Meminimalkan penyalahgunaan anggaran sekolah.

Disamping itu sekolah sebagai organisasi nirlaba/non bisnis dalam rangka transparansi dan akuntabilitias pengelolaan keuangan, sekolah harus menyusun laporan keuangan sesuai dengan tujuan laporan keuangan yang dirumuskan oleh Financial Accounting Standarts Board (FASB,1980) yang telah mengeluarkan Statement of Financial Accounting Concepts No.4 (SFAC 4) sebagai berikut : (Mardiasmo 2002)

1) Laporan keuangan organisasi non bisnis hendaknya dapat memberikan informasi yang bermanfaat bagi penyedia dan calon penyedia sumberdaya, serta pemakai dan calon pemakai lainnya dalam pembuatan keputusan yang rasional mengenai alokasi sumber daya organisasi.

2) Memberikan informasi untuk membantu para penyedia dan calon penyedia sumberdaya serta pemakai dan calon pemakai lainnya dalam menilai pelayanan yang diberikan oleh organisasi non bisnis serta kemampuannya untuk melanjutkan memberi pelayanan tersebut.

3) Memberikan informasi yang bermanfaat bagi penyedia dan calon penyedia sumber daya serta pemakai dan calon pemakai lainnya dalam menilai kinerja manajer organisasi non bisnis atas pelaksanaan tanggungjawab pengelolaan serta aspek kinerja lainnya.

4) Memberikan informasi mengenai sumberdaya ekonomi, kewajiban 
dan kekayaan bersih organisasi , serta pengaruh dari transaksi, peristiwa dan kejadian ekonomi yang mengubah sumberdaya dan kepentingan sunberdaya tersebut.

5) Memberikan informasi mengenai kinerja organisasi selama satu periode. Pengukuran secara periodik atas perubahan jumlah dan keadaan/kondisi sumber kekayaan bersih organisasi non bisnis serta informasi mengenai usaha dan hasil pelayanan organisasi secara bersama-sama yang dapat menunjukkan informasi yang berguna untuk meniliai kinerja.

6) Memberikan informasi mengenai bagaimana organisasi memperoleh dan membelanjakan kas atau sumberdaya kas, mengenai utang dan pembayaran kembali utang, dan mengenai faktor-faktor lain yang dapat mempengaruhi likuiditas organisasi.

7) Memberikan penjelasan dan interpretasi untuk membantu pemakai dalam memahami informasi keuangan yang diberikan.

Untuk mencapai tujuan tersebut, maka dibutuhkan kreativitas kepala sekolah dalam menggali sumbersumber dana, menempatkan bendaharawan yang menguasai dalam pembukuan dan pertanggungjawaban keuangan serta memanfaatkannya secara benar sesuai peraturan perundang-undangan yang berlaku.

\section{Komponen Utama Manajemen Keuangan Sekolah}

Pelaksanaan manajemen keuangan menganut azas pemisahan tugas antara fungsi otorisator, ordonator dan bendaharawan. Otorisator adalah pejabat yang diberi wewenang untuk mengambil tindakan terkait penerimaan dan pengeluaran anggaran.

Ordonator adalah pejabat yang berwenang melakukan pengujian dan memerintahkan pembayaran atas segala tindakan yang dilakukan berdasarkan otorisasi yang telah ditetapkan. Adapun bendaharawan adalah pejabat yang berwenang melakukan penerimaan, penyimpanan dan pengeluaran uang atau surat-surat berharga lainnya yang dapat dinilai dengan uang serta diwajibkan membuat perhitungan dan pertanggung jawaban (Suryana 2008:38). Kepala sekolah dalam hal ini sebagai manajer, berfungsi sebagai otorisator, dan dilimpahi fungsi ordonator untuk memerintahkan pembayaran. Namun, tidak dibenarkan melaksanakan fungsi bendaharawan karena berkewajiban melakukan pengawasan ke dalam. Bendaharawan, disamping mempunyai fungsi-fungsi bendaharawan, juga dilimpahi fungsi ordonator untuk menguji hak atas pembayaran.

Adapun komponen manajemen keuangan (Suryana 2008:39) meliputi :

1) prosedur anggaran

2) prosedur akuntansi keuangan,

3) pembelajaran, pergudangan dan prosedur pendistribusian,

4) prosedur investasi, dan

5) prosedur pemeriksaan

\section{Prinsip-prinsip pengelolaan Manajemen Keuangan Sekolah}

Penggunaan anggaran dan keuangan dari sumber manapun, apakah itu dari pemerintah ataupun dari masyarakat perlu didasarkan pada prinsip-prinsip umum pengelolaan keuangan, adapun prinsip-prinsip pengelolaan keuangan pendidikan menurut Suryana (2008:41) sebagai berikut:

1) Hemat, tidak mewah, efisien dan sesuai dengan kebutuhan teknis yang disyaratkan.

2) Terarah dan terkendali sesuai dengan rencana, program/kegiatan.

3) Terbuka dan transparan, dalam pengertian dari dan untuk apa keuangan lembaga tersebut perlu dicatat dan dipertanggungjawabkan serta disertai bukti penggunaannya. 
4) Sedapat mungkin menggunakan kemampuan/hasil produksi dalam negeri sejauh hal ini dimungkinkan.

\section{Rencana Anggaran Pendapatan Dan Belanja Sekolah (RAPBS)}

Implementasi prinsip-prinsip keuangan di atas pada pendidikan, khususnya di lingkungan sekolah dan keserasian antara pendidikan dalam keluarga, dalam sekolah, dan dalam masyarakat, maka untuk sumber dana sekolah, sekolah itu tidak hanya memperoleh anggaran dan fasilitas dari pemerintah atau penyandang dana tetap saja, tetapi dari sumber dari ketiga komponen di atas. Untuk itu di sekolah sebenarnya juga perlu dibentuk organisasi orang tua siswa yang implementasinya dilakukan dengan membentuk komite sekolah. Komite tersebut beranggotakan wakil orang tua/wali siswa, tokoh masyarakat, pengelola, wakil pemerintah dan wakil ilmuwan/ulama di luar sekolah dan dapat juga memasukkan kalangan dunia usaha dan industri (Permendiknas No.44 Tahun 2003).

Sekolah bersama komite atau majelis sekolah pada setiap awal tahun anggaran perlu bersama-sama merumuskan Rencana Anggaran Pendapatan Dan Belanja Sekolah (RAPBS) sebagai acuan bagi pengelola sekolah dalam melaksanakan manajemen keuangan sekolah yang baik.

\section{Pengertian RAPBS}

Menurut Suryana (2008) anggaran adalah rencana yang diformulasikan dalam bentuk rupiah dalam jangka waktu atau periode tertentu, serta alokasi sumber-sumber kepada setiap bagian kegiatan. Anggaran memiliki peran penting di dalam perencanaan, pengendalian dan evaluasi kegiatan yang dilakukan sekolah. Maka seorang penanggungjawab program kegiatan di sekolah harus mencatat anggaran serta melaporkan realisasinya sehingga dapat dibandingkan selisih antara anggaran dengan pelaksanaan serta melakukan tindak lanjut untuk perbaikan. Masih menurut Suryana (2008:41), ada dua bagian pokok anggaran yang harus diperhatikan dalam penyusunan RAPBS, yaitu:

1) Rencana sumber atau target penerimaan/pendapatan dalam satu tahun yang bersangkutan, termasuk di dalamnya keuangan bersumber dari:

a) kontribusi orang tua siswa,

b) sumbangan dari individu atau organisasi,

c) sumbangan dari pemerintah,

d) dari hasil usaha

2) Rencana penggunaan keuangan dalam satu tahun yang bersangkutan, semua penggunaan keuangan sekolah dalam satu tahun anggaran perlu direncanakan dengan baik agar kehidupan sekolah dapat berjalan dengan baik pula.

\section{Langkah-langkah Penyusunan RAPBS}

Dalam penyusunan RAPBS adalah harus menerapkan prinsip anggaran berimbang, artinya rencana pendapatan dan pengeluaran harus berimbang dan diupayakan tidak terjadi anggaran pendapatan minus. Dengan anggaran berimbang tersebut maka kehidupan sekolah akan menjadi solid dan benar-benar kokoh dalam hal keuangan, maka sentralisasi pengelolaan keuangan perlu difokuskan pada bendaharawan sekolah, dalam rangka untuk mempermudah pertanggung jawaban keuangan. Adapun langkah-langkah penyusunan RAPBS menurut Suryana (2008:44) adalah sebagai barikut :

1) Menginventarisasi rencana yang akan dilaksanakan.

2) Menyusun rencana berdasarkan skala prioritas pelaksanaannya. 
3) Menentukan program kerja dan rincian program.

4) Menetapkan kebutuhan untuk pelaksanaan rincian program.

5) Menghitung dana yang dibutuhkan.

6) Menentukan sumber dana untuk membiayai rencana.

Rencana tersebut setelah dibahas dengan pengurus dan komite sekolah, maka selanjutnya ditetapkan sebagai anggaran pendapatan dan belanja sekolah (APBS) setelah dilakukan pemeriksaan oleh Dinas Pendidikan di tingkat Kabupaten/Kota. Pada setiap anggaran yang disusun perlu dijelaskan apakah rencana anggaran yang akan dilaksanakan merupakan hal baru atau kelanjutan atas kegiatan yang telah dilaksanakan dalam periode sebelumnya dengan menyebut sumber dana sebelumnya.

Dalam setiap anggaran yang disusun untuk kegiatan-kegiatan di lingkungan sekolah, menurut Suryana (2008:45) paling tidak harus memuat 6 hal atau informasi sebagai berikut:

1) Informasi rencana kegiatan : sasaran, uraian rencana kegiatan, penanggungjawab, rencana baru atau lanjutan.

2) Uraian kegiatan program, program kerja, rincian program.

3) Informasi kebutuhan : barang/jasa yang dibutuhkan, volume kebutuhan.

4) Data kebutuhan harga satuan, jumlah biaya yang dibutuhkan untuk seluruh volume kebutuhan.

5) Jumlah anggaran : jumlah anggaran untuk masing-masing rincian program, program, rencana kegiatan, dan total anggaran untuk seluruh rencana kegiatan.

6) Sumber dana : total sumber dana, masing-masing sumber dana yang mendukung pembiayaan program.

\section{Realisasi APBS}

Dalam pelaksanaan kegiatan, jumlah yang direalisasikan bisa terjadi tidak sama dengan rencana anggarannya, bisa kurang atau lebih dari jumlah yang telah dianggarkan. Ini dapat terjadi karena beberapa sebab (Suryana 2008:52) :

1) Adanya efisiensi atau inefisiensi pengeluaran

2) Terjadinya penghematan atau pemborosan

3) Pelaksanaan kegiatan yang tidak sesuai dengan yang telah diprogramkan

4) Adanya perubahan harga yang tidak terantisipasi.

5) Penyusunan anggaran yang kurang tepat.

\section{Pertanggung Jawaban Keuangan Sekolah}

Semua pengeluaran keuangan sekolah dari sumber manapun harus dipertanggungjawabkan, hal tersebut merupakan bentuk transparansi dalam pengelolaan keuangan. Namun demikian prinsip transparansi dan kejujuran dalam pertanggungjawaban tersebut harus tetap dijunjung tinggi. Dalam kaitan dengan pengelolaan keuangan tersebut, yang perlu diperhatikan oleh bendaharawan menurut Suryana (2008:58) adalah:

1) Pada setiap akhir tahun anggaran, bendahara harus membuat laporan keuangan kepada komite sekolah untuk dicocokkan dengan RAPBS.

2) Laporan keuangan tersebut harus dilampiri bukti-bukti pengeluaran yang ada.

3) Kwitansi atau bukti pembelian atau bukti penerimaan dan bukti pengeluaran lain.

4) Neraca keuangan juga harus ditunjukkan untuk diperiksa oleh tim pertanggungjawaban keuangan dari komite sekolah.

\section{METODE PENELITIAN}

\section{Desain penelitian}

Menurut M. Nazir (2005 : 36), bahwa desain penelitian adalah suatu 
rencana kerja yang terstruktur dan konprehensif mengenai hubunganhubungan antar variabel yang disususn sedemikian rupa agar hasil penelitiannya dapat memberikan jawaban atas pertanyaan-pertanyaan penelitian. Dalam perencanaan tersebut mengcakup hal-hal yang akan dilakukan peneliti mulai dari membuat hipotesis dan implikasinya secara operasional sampai pada analisis akhir.

\section{Metode Pengumpulan Data}

1. Interview, yaitu pengumpulan data yang dilakukan cara melakukan wawancara langsung dengan pihak-pihak yang mengetahui tentang masalah yang diteliti.

2. Dokumentasi, yaitu pengumpulan data yang dilakukan dengan mengumpulkan dokumen-dokumen yang ada hubungannya dengan masalah yang diteliti.

3. Kuisioner, yaitu menyebarkan angket yang berisi pertanyaanpertanyaan atau pernyataanpernyataan yang memiliki hubungan dengan masalah yang diteliti. Kusioner ini bertujuan untuk mengumpulkan data primer yang akan dianalisis.

\section{Jenis dan Sumber Data}

1. Data primer, yaitu data yang bersumber dari lokasi penelitian berupa data utama yang akan dianalisis, dalam hal ini data yang diperoleh melalui pembagian angket atau kuisioner kepada responden.

2. Data sekunder, yaitu data kedua dan berfungsi sebagai data pendukung dalam memecahkan pokok permasalahan yang menajdi obyek penelitian.

\section{Populasi}

Populasi dalam penelitian ini adalah seluruh guru dan staf tata usaha yang ada di pada MTs Salilama
Kecamatan Mananggu Kabupaten Boalemo yang berjumlah 14 orang responden. Metode pengambilan sampel dalam penelitian ini menggunakan sampling jenuh (sensus). Menurut Sugiyono (2004:44) sampling jenuh adalah teknik pengambilan sampel bila semua anggota populasi digunakan sebagai sampel karena jumlah populasi kecil dan relatif heterogen.

\section{Metode Analisis}

Analisa data adalah proses mencari dan menyusun secara sistematis data yang diperoleh dari observasi (catatan lapangan), wawancara, dan dokumentasi dengan cara mengorganisasikan data ke dalam kategori, menjabarkan ke dalam unitunit, melakukan sintesa, menyusun ke dalam pola, memilih mana yang penting dan yang akan dipelajari, dan membuat kesimpulan sehingga mudah difahami oleh diri sendiri maupun orang lain. Setelah data terkumpul dari pengumpulan data, maka penulis segera menganalisa data. Untuk menganalisa data, penulis menggunakan langkah-langkah sebagai berikut :

1. Editing. Setelah penelitian selesai menghimpun data di lapangan data tersebut perlu diedit terlebih dahulu sebelum data diolah, dengan kata lain, data atau keterangan yang telah dikumpulkan dalam record book, daftar pertanyaan ataupun pada interview guide perlu dibaca sekali lagi dan diperbaiki jika masih terdapat hal-hal yang masih meragukan, Sugiyono (2005:89).

2. Pengkodean. Setelah tahap editing selesai dilakukan, kegiatan berikutnya adalah mengklasifikasikan data-data tersebut melalui tahapan koding. Maksudnya bahwa data yang telah diedit tersebut diberi identitas 
sehingga memiliki arti tertentu pada saat dianalisis.

3. Tabulasi (Proses Pembeberan). Tabulasi merupkan bagian terakhir dari pengolahan data. Dengan memasukkan data pada tabel-tabel tertentu dan mengatur angka-angka sehingga dapat dihitung jumlah kasus dalam berbagi kategori.

$$
\mathrm{P}=\frac{\mathrm{F}}{\mathrm{N}} \mathrm{X} 100 \%
$$

Keterangan:

$\mathrm{P}=$ Angka persentase

$\mathrm{F}=$ Frekuensi (Jumlah responden) jawaban

$\mathrm{N}=$ Number of cases (jumlah responden)

Penafsiran Data. Merupakan penjelasan yang terperinci tentang arti yang sebenarnya dari materi yang dipaparkan. Data yang telah dalam bentuk tabel, misalnya, perlu diberikan penjelasan yang terperinci.

\section{PEMBAHASAN}

Lembaga pendidikan MTs Salilama dalam menyusun perencanaan keuangan sekolah dilakukan ketika akan memasuki awal tahun pembelajaran baru dimulai dengan melibatkan tenaga pendidik terkait serta dalam penyusunan perencanaan keuangan sekolah atau Rancangan Anggaran Pendapatan dan Belanja Sekolah (RAPBS) pihak pengelola MTs Salilama nampaknya berusaha untuk menyusun Rancangan Anggaran Pendapatan Belanja Sekolah (RAPBS) berdasarkan pada efektif dan efesien. Hal ini menunjukkan bahwa MTs Salilama telah memperhitungkan segala bentuk kebutuhan dengan cermat dan tepat guna sehingga terwujudnya proses pembelajaran yang telah ditetapkan. Pihak Pengelola MTs Salilama senantiasa berkoordinasi kepada pihak komite sekolah baik mengenai kebutuhan dana maupun mengenai kegiatan lainnya. Hal ini menunjukkan adanya hubungan yang harmonis antara pihak pengelola MTs Salilama dengan pihak komite sekolah. Dengan terjalinnya hubungan yang harmonis akan lahir programprogram unggulan, dengan adanya program-program unggulan. Setelah penyusunan RAPBS selesai dibuat, maka pihak pengelola MTs Salilama menyerahkan kepada penanggung jawab keuangan pada MTs Salilama.

Dalam hal ini menunjukkan bahwa pola pengelolaan keuangan sekolah yang terkoordinir serta terencana inilah menjadi salah satu bagian dari faktor yang membesarkan nama MTs Salilama. Kegiatan evaluasi keuangan sekolah yang berlaku hingga penulisan ini berlangsung dilakukan pada akhir semester dengan melibatkan tenaga terkait penggunaan keuangan sekolah.

Pembuatan laporan pertanggung jawaban atas penggunaan keuangan sekolah yang berlaku di MTs Salilama maksimal 10 hari kerja, hal ini diberlakukan sebagai wujud pembuktian dan penentuan bahwa apa yang dimaksud sesuai dengan yang dilakukan, sedang bahwa apa yang dilakukan sesuai dengan tugas. Laporan pertanggungjawaban yang telah dipelajari dan dikaji oleh pihak manajemen MTs Salilama dengan bagian Keuangan dijadikan sebagai bahan referensi dalam meningkatkan efektif dan efesien baik ketika penyusunan maupun ketika pengelolaan keuangan tersebut.

Dalam pelaksanaan manajemen keuangan sekolah yang berlaku pihak manajemen keuangan sekolah terkadang mengalami kendala sebesar $29 \%$, namun kendala yang dihadapi pihak manajemen sekolah mengadakan pertemuan guna mendapatkan solusi yang terbaik hal ini terlihat dari hasil analisa data sebesar $71 \%$. 


\section{KESIMPULAN}

Berdasarkan hasil penelitian dan pembahasan dapat disimpulkan bahwa Pengelolaan keuangan sekolah pada MTs Salilama Kecamatan Mananggu Kabupaten Boalemo sudah efektif, sebab dalam hal ini Lembaga pendidikan MTs Salilama dalam menyusun perencanaan keuangan sekolah dilakukan ketika akan memasuki awal tahun pembelajaran baru dimulai dengan melibatkan tenaga pendidik terkait dan komite sekolah serta dalam penyusunan perencanaan keuangan sekolah atau Rancangan Anggaran Pendapatan dan Belanja Sekolah (RAPBS) pihak pengelola MTs Salilama nampaknya berusaha untuk menyusun Rancangan Anggaran Pendapatan Belanja Sekolah (RAPBS) berdasarkan pada efektif dan efesien yang sesuai dengan tanggapan responden sebesar $100 \%$.

Namun dalam pelaksanaan manajemen keuangan sekolah yang berlaku pihak manajemen keuangan sekolah mengalami sedikit kendala, namun kendala yang dihadapi pihak manajemen sekolah mengadakan pertemuan guna mendapatkan solusi yang terbaik, hal ini terlihat pada hasil tanggapan responden sebesar $71 \%$.

\section{DAFTAR PUSTAKA}

Bastian. Indra. 2007. Akuntansi Pendidikan. Penerbit Erlangga. Jakarta

Depdiknas Didasmen TK \& SD, Manajemen Berbasis Sekolah untuk Sekolah Dasar. Jakarta: Depdiknas, 2002.

Irham Fahmi. 2011. Analisis Laporan Keuangan. Alfabeta, Bandung. Mardiasmo. "Otonomi Daerah sebagai upaya memperkokoh Perekonomian Daerah", Jurnal Ekonomi Rakyat Th I No. 4, Juni 2002
Mulyasa, Manajemen Berbasis Sekolah. 2007. Bandung. Remaja Rosda Karya.

Nasir. M. 2005, Metode Skripsi, Penerbit Ghalia Indonesia, Bogor

Permendiknas Nomor 44 Tahun 2003, Tentang Pedoman Pembentukan Dewan Pendidikan dan Komite Sekolah

Sagala, S. (2008). Manajemen Strategik dalam Peningkatan Mutu Pendidikan. Bandung: Alfabeta

Sugiyono, Metode Skripsi Kuantitatif, Kualitatif Dan $R$ \& D, 2005, Alfabeta Bandung

Suryana. Deden, 2008. Manajemen Keuangan Sekolah, Oktober.

Undang-Undang Nomor 20 Tahun 2003 Tentang Sistem Pendidikan Nasional. 